\title{
Understanding the EU-Singapore Free Trade Agreement
}

\author{
Deborah Elms
}

Abstract

Initial negotiations on a free trade agreement (FTA) between the European Union (EU) and the Association of Southeast Asian Nations (ASEAN) began in 2007. Although the quest for a region-wide deal quickly foundered, the EU soon shifted focus to negotiating with key, individual member states in ASEAN. Singapore was targeted to sign the first agreement and negotiations got underway in 2010. The EUSingapore FTA was completed in 2014, with the remaining issues in the investment chapter finished by May 2015. The final outcome is a relatively high-quality deal, with nearly all tariffs dropped between the two parties, new openings in services markets, some additional rules in areas like intellectual property rights and government procurement, and a robust investment chapter. Implementation of the agreement got delayed, however, pending internal procedures in Europe. Officials are hoping for the deal to enter into force sometime after a ruling from the European Court of Justice, delivered on 16 May 2017. 


\section{Rationale for an agreement}

In 2007, the EU launched negotiations with ASEAN to create a megaregional FTA. Such a trade agreement would hook together two large and diverse regional actors - the then 27 members of the EU (EU27) with 10 members of ASEAN (Brunei, Cambodia, Indonesia, Laos, Malaysia, Myanmar, Philippines, Singapore, Thailand and Vietnam).

Taken as a bloc, ASEAN represented a large and growing economic market for the EU, as shown in Figure 1. Trade in goods with ASEAN was larger than trade with Japan, Brazil, India and the Gulf states. Services trade was also significant and growing. Finally, foreign direct investment was substantial. The economic impetus for a deal to more closely connect the two regions was clear.

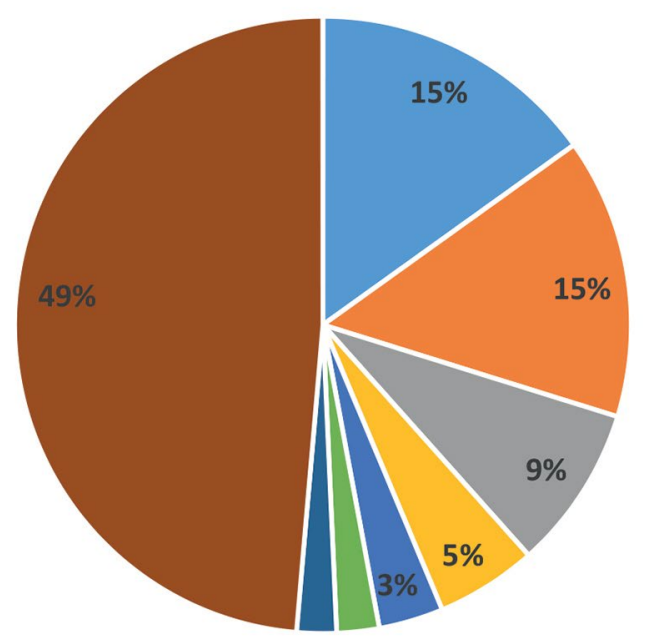

$2 \% 2 \%$
- USA

- China \& Hong Kong

- Russia

ASEAN

- Japan

- India

- Brazil

- Other

Figure 1. Key EU partners in goods trade (2012)

Source: Eurostat 2013. 
However, shortly after negotiations got underway, the Europeans quickly understood that while the EU negotiates as a genuine bloc, ASEAN does not. When negotiating with ASEAN, at least 11 people are seated at the table-one person from each of the member states plus someone from the ASEAN Secretariat. Secretariat staff are largely unable to commit to anything on behalf of their members. Creating an agreement with ASEAN essentially meant creating 10 separate bilateral agreements in key areas (like market access schedules for goods, services and investment) with, potentially, a few common elements across all ASEAN members.

The EU decided that, if it was going to have to negotiate more than one agreement, it might get better terms and an easier negotiating path by starting with key markets on an individual basis. This meant launching bilateral talks with Singapore, Malaysia, Vietnam and Thailand. ${ }^{1}$

\section{EU-Singapore negotiations}

On the surface, Singapore did not appear to be a particularly interesting market for Europe. The total population of roughly five million included a substantial number of foreign workers with limited capacity to consume European goods and services. However, this picture does not accurately reflect the actual importance of the Singapore market. Singapore dominated trade within ASEAN vis-à-vis Europe. Figures 2-4 highlight the importance of the Singapore market. For example, Singapore alone accounted for more than $€ 42$ billion in exports for European companies, while the region imported $€ 35$ billion in goods and services from Singapore. Of equal interest was the substantial stock of foreign direct investment (FDI). Table 1 shows that the EU had more money invested in Singapore ( $€ 126$ billion) in 2012 than in the United States of America (USA) ( $€ 65$ billion) by more than double. Singapore's investments into the EU were also significant at $€ 55$ billion. The total number of European companies resident in Singapore approached 9,000.

1 Of course, the EU was actually composed of 27 distinct members, so the agreement is not technically a 'bilateral' deal between two nations. But the EU effectively negotiates as one, particularly (as noted further below) after the Lisbon Treaty changed competence of investment to the EU level instead of member state levels. This meant that all aspects of trade negotiations could be handled by the European Commission on behalf of its members. 


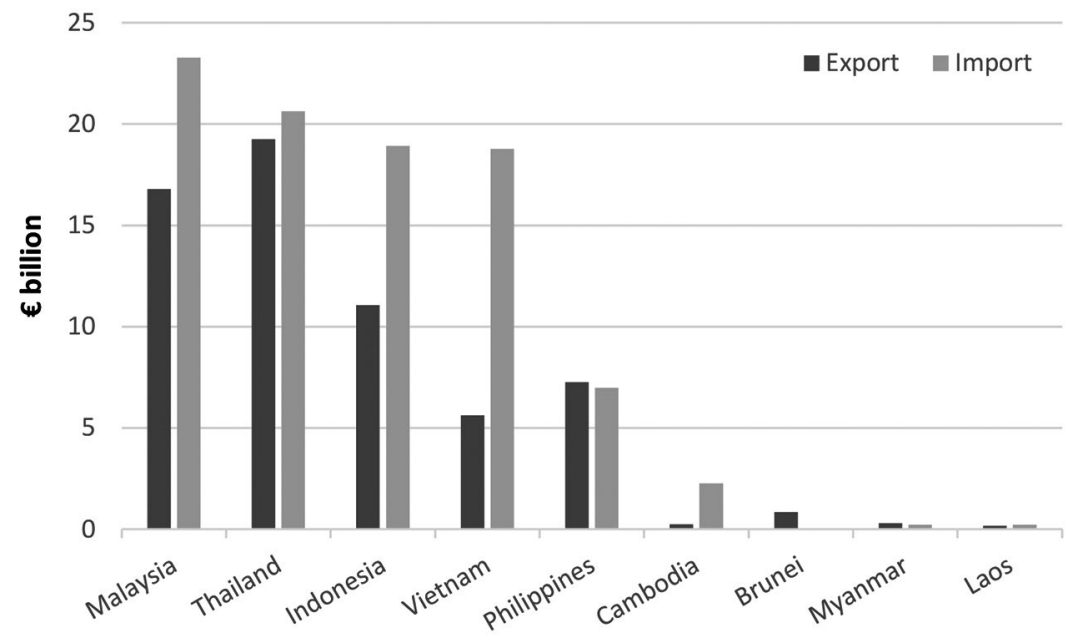

Figure 2. EU trade in goods and services with ASEAN (2012)

Source: Eurostat 2013.

- 29 Organic chemicals

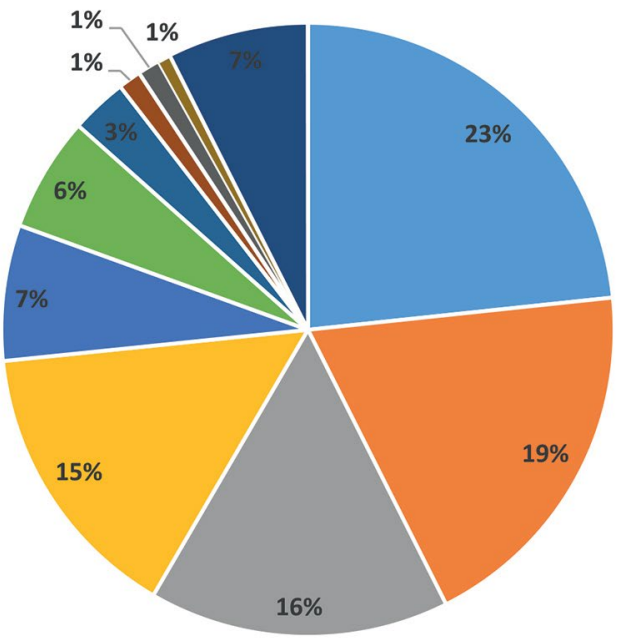

- 84 Machinery and mechanical appliances

- 85 Electrical machinery and equipment

- 30 Pharmaceuticals

- 90 Optical, photographic, other fine instruments

- 27 Mineral fuels, oils, products

- 89 Ships

- 39 Plastics, plastic articles

- 71 Pearls, precious stones \& metals, jewellery

- 38 Miscellaneous chemical products

- Other

Figure 3. EU27 top imports from Singapore (2012)

Source: Eurostat 2013. 


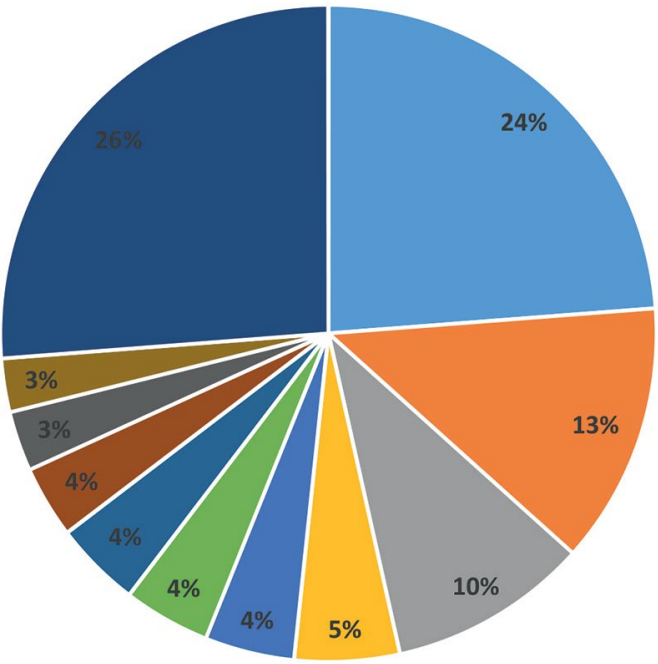

- 84 Machinery and mechanical appliances

= 85 Electrical machinery and equipment

- 27 Mineral fuels, oils, products

= 90 Optical, photographic, other fine instruments

- 22 Beverages

$\llbracket 88$ Aircraft, parts

- 87 Automotive vehicles, parts

- 30 Pharmaceuticals

- 89 Ships

- 33 Essential oils, cosmetics, toilet preparations

- Other

Figure 4. EU27 top exports to Singapore (2012)

Source: Eurostat 2013.

Table 1. Value of foreign direct investment (FDI) in 2011

\begin{tabular}{|l|r|r|}
\hline FDI source & $\begin{array}{r}\text { Investment stock into } \\
\text { Singapore (€ billion) }\end{array}$ & $\begin{array}{r}\text { Investment stock into } \\
\text { the EU (€ billion) }\end{array}$ \\
\hline EU & 107.3 & 67 \\
\hline Singapore & & 144 \\
\hline USA & 43.1 & \\
\hline Japan & 29.1 & \\
\hline Switzerland & 15.9 & 10 \\
\hline ASEAN-9 & 14.2 & 64 \\
\hline India & 13.2 & \\
\hline Hong Kong & 13.0 & 4 \\
\hline Norway & 12.1 & 15 \\
\hline Malaysia & 10.3 & \\
\hline China & 8.1 & \\
\hline
\end{tabular}

Sources: Singapore's figures from Department of Statistics, May 2013; EU from Eurostat 2013. 
Hence, Singapore represented an attractive market all on its own as a trade agreement partner. Singapore also had growing interest and experience negotiating FTAs. Much of what the country had promised to the Americans in a 2005 bilateral agreement could potentially be replicated in a negotiation with the EU. This would represent a very high-quality, ambitious FTA for Europe.

Finally, if the EU succeeded in crafting a solid FTA with Singapore, it could serve as the template for a future agreement with ASEAN. The Singaporeans would go first and likely finish negotiating the fastest. Thus an EU-Singapore FTA (EUSFTA) bilateral could serve as a model for negotiations with other countries such as Malaysia and Thailand. Furthermore, keeping consistency across ASEAN-member FTAs could make it easier to combine six agreements into one (with Singapore, Malaysia, Thailand, Philippines, Indonesia and Vietnam). Cambodia, Laos and Myanmar were not invited to join in bilateral negotiations with the EU, but these countries already received preferential access to Europe through 'Everything But Arms' trading schemes. The last ASEAN member, Brunei, was simply not an important enough bilateral partner to warrant separate negotiations. It would have to wait until the regional agreement was ready and be folded in at that time. Hence, by the end of the process, the Europeans could combine enough 'building block' agreements to finally wrap up a region-to-region deal.

\section{Economic benefits of the agreement}

Negotiations commenced with Singapore in 2010. The basic framework was finished by 2012 , with a few minor issues remaining. As discussed in greater detail below, sticking points included geographical indications, financial services and investment rules. The deal (except for investment) was finished by October 2014. In May 2015, both sides announced the conclusion of the agreement, when the final legal scrubbing was completed for the investment chapter (see Ministry of Trade and Industry, Singapore, 2015). The European Court of Justice (ECJ) decided in May 2017 on whether only the European Parliament must ratify the FTA or whether member states would also have to approve portions of the final agreement. The ruling provided for 'mixed competence', showing that the EU could 
determine most of the agreement, but some elements, including parts of investment, will require member state approval. The EUSFTA allows for a provisional entry into force once the Court ruling is completed. ${ }^{2}$

Modelling of the economic benefits of the agreement appeared quite lopsided, with the majority of gains flowing to the Singapore side. This reflects the significant differences in economic size between the two parties. The Chief Economist of the European Commission estimated that EU exports to Singapore could increase by $€ 1.4$ billion over 10 years while Singaporean exports to the EU could increase by $€ 3.5$ billion. Real gross domestic product (GDP) in the EU could grow by $€ 550$ million while Singapore could see an increase of $€ 2.7$ billion (see Delegation of the European Union to the United States 2015).

Note also that economic modelling usually handles comprehensive FTAs badly. This is because the economic models overemphasise the importance of tariff reductions (which are easy to measure and straightforward to model) and underemphasise the importance of services and investment changes (which are very tricky to measure and hard to model, particularly with knock-on effects likely). In addition, firms are increasingly concerned about the proliferation of non-tariff barriers (NTBs), such as incompatible or complex standards, testing regimes, labelling laws, delays in processing shipments at the border and so forth. NTB reductions are nearly impossible to include in economic modelling. Hence, while economic modelling is a useful exercise and can provide information about the expected direction of economic growth as well as handy figures for political leaders to press for changes, the real-world impact of FTAs can be much greater or different than economic models suggest.

In the case of the EUSFTA, models will likely also fail to capture the potential for increased regional economic growth by European companies using Singapore as a platform for further expansion into ASEAN. Most of the European companies located in Singapore prior to the FTA used the island as a base for regional strategies. There is every reason to expect this pattern to continue and to accelerate after the FTA takes effect.

2 For the complete text of the agreement, see European Commission (2015). 
Finally, the EUSFTA has always been intended-from the European perspective-to form the basis for the larger regional agreement with ASEAN. Thus, the European Commission and member states have long recognised that while benefits from a bilateral agreement with Singapore may be lopsided, the benefits from the expansion of an FTA to encompass all of ASEAN will likely be substantial for European companies.

\section{Exploring the EUSFTA in detail}

So, what happened in the EUSFTA? In brief, the bilateral agreement represents a relatively high-quality outcome. This result was easier to obtain than in many negotiations, given the comparatively open nature of the Singapore market. For example, Singapore's applied tariff rate for all goods (except for six tariff lines for some alcohol products and cigarettes) is zero. This always makes it easier to craft a trade agreement, since Singapore has fewer built-in sensitivities in goods that must be accommodated.

The agreement covers most goods, including a few new provisions on electronics and a consultation process for agricultural trade regulations. Several important sectors have specific coverage under the agreement. Services trade was also opened and liberalised with a clear eye towards crafting an ASEAN-wide deal on services for the future.

The agreement also included provisions on government procurement, new rules on intellectual property rights including a greatly expanded set of covered geographical indications, a chapter on competition, development objectives, labour standards and dispute settlement procedures. Each of these elements is covered in more detail below.

\section{Trade in goods}

Given Singapore's duty-free applied access to goods, the EUSFTA binds Singapore tariffs at 0 for European goods imports. The bulk of the negotiations focused on tariff reductions for the European side. Basically, the EU agreed to reduce its own tariffs to match the levels found in the 2011 EU-Korea FTA within 5 years of entry into force. This included dropping tariffs to 0 on entry into force for approximately 75 per cent of tariff lines. Most of the remaining lines were also scheduled to go to 0 across a time period of 3-5 years, with reductions taking place in annual installments. 
A goods agreement cannot be evaluated on the basis of tariff line reductions alone, however. Trade between parties is often concentrated, so the bulk of actual trade between members in an FTA might take place in a handful of tariff lines alone. If these lines are not included in the final agreement, a headline figure of even 95 per cent tariff reductions may not translate into meaningful economic outcomes on the ground. However, EU-Singapore trade is relatively widely dispersed, making it more likely that tariff cuts would affect tradeable sectors like machinery, chemicals and pharmaceuticals.

Tariffs also interact with rules of origin. Rules of origin are necessary to ensure that only firms from member countries are eligible to receive the benefits (particularly lower tariff rates) built into the agreement. If any company could take advantage of the deal, it would undermine the specific benefits for members. Hence, every FTA comes with rules of origin to ensure that products claiming preferences are either wholly 'from' members (i.e. grown, produced, mined or extracted from the member without any additional content added from any other member state) or are substantially transformed from their original materials or components into a new type of product within the geographic spaces covered by the FTA.

It is possible to create an agreement with zero tariffs across the board, but make the requirements for receiving duty-free treatment so onerous that almost no firms are able to take advantage of the lower tariff rates. Or, conversely, it is possible to have tariffs drop by less, but make it so easy for firms to use the agreement that nearly all companies participate in the agreement. ${ }^{3}$

There is no agreement among firms on what type of rules are easiest to use. For some companies, blanket rules (such as requiring $40-45$ per cent of the content embedded in a product to come from member states) are preferable to more specific rules for each product. These blanket rules can apply to

3 Companies never get the benefits of an FTA automatically—each FTA requires firms to certify that they are using an FTA. The method of certification varies, but often FTAs require a certificate of origin to be obtained from a local chamber of commerce or another designated body before customs officers at the border will grant lower tariffs. Without a certificate of origin (or self-certification in some newer generation agreements), products cannot qualify for the preferential rate and are instead charged the most-favoured-nation (MFN) rate. The MFN tariff rate is the tariff charged to all World Trade Organization (WTO) members automatically without requiring any certification of origin. Since more than 160 countries are WTO members, practically speaking, nearly all firms can use MFN rates for their goods shipments. For many firms, unless the preferential benefits of an FTA are substantial, companies often opt to avoid the hassle required in using the provisions of an FTA and ship goods under MFN tariffs. 
every item in a firm's inventory, so once a company works out the value of the content for each product, it can determine easily which will be allowed to claim preferences and which (absent reformulation or shifts in the supply chain) cannot. However, some firms prefer more specific rules. Productspecific rules grant less flexibility to customs officials in evaluating products at the border. Product-specific rules can also be subject to fewer disputes and may be less at risk to shifting prices in raw materials, components, labour and even exchange rate fluctuations (since products that reach, for example, 43 per cent value content today may be only 38 per cent value content tomorrow if the prices shift in determining the product values).

The EUSFTA contains mostly product-specific rules of origin. The agreement includes some co-equal rules (which allow firms to use one or the other of two calculation methods to prove sufficient content). The agreement is effectively a bilateral agreement between the EU (counting EU members as if they were one) and Singapore. Hence, the agreement does not allow content from across ASEAN to count towards content. This can be a problem for Singapore, since the country has very few indigenous items to add to a product's content. Singapore's major exports to the EU include oil and oil-related products, manufactured goods (especially electronics), and pharmaceuticals. With raw materials, parts and components usually coming from overseas, it is not always possible to reach high levels of locally added content, absent the ability to add up, or cumulate, content from elsewhere. Nevertheless, as the EU moves towards incorporating all the bilateral trade agreements into one region-wide ASEAN agreement, it is likely that ASEAN cumulation rules will be built in the future.

The EU did not pledge to reach duty-free status in all products. The EUSFTA left some items that will not be subject to tariff elimination including some fish products (tilapia, catfish, salmon in vegetable oil, bonito and surimi); as well as chemically pure fructose; and sweetcorn and maize.

Specific customs duties will remain for some vegetable and fruit products imported into Europe, including vegetables (fresh or chilled tomatoes, cucumbers, globe artichokes and courgettes); citrus (including fresh sweet oranges, clementines, monreales and satsumas, mandrins and wilkings, tangerines and lemons); and fruits (including table grapes, apricots, sour cherries, nectarines and plums). ${ }^{4}$

4 For the specific exceptions, please see the market access schedules of the EU found in Annex 2-A of European Commission (2015). 


\section{Other goods provisions}

The agreement included an additional chapter on what are called technical barriers to trade. These are largely regulatory and standards-based rules that govern specific types of goods. The EUSFTA sets up a rudimentary structure to strengthen cooperation in regulatory areas in the future, as well as better procedures for exchanging information and streamlining regulations between the parties.

One exception to the largely generic nature of the technical barriers to trade rules can be found in an annex on electronics. Singapore has an unusually complex system of testing in this sector. The agreement contains promises to use conformity assessments and international standards bodies as much as possible.

Another chapter covers rules for food and food safety. The sanitary and phytosanitary chapter codified that both sides could have import requirements for food and food stuffs. Imports can be stopped and checked for compliance with relevant sanitary and phytosanitary rules, under a set of procedures that was tightened and clarified with specific timelines for inspections. The agreement sets out a variety of committees and consultations to take place around sanitary and phytosanitary issues in the future.

Finally, the agreement also sets out four sector-specific provisions. For motor vehicles, Singapore agreed to recognise EU standards and testing regimes for cars and car parts. The agreement also has language on green rebates for more environmentally friendly motor vehicles. A second section covers electronics, where Singapore agreed to gradually replace third-party testing of products (particularly to accept suppliers' declarations of conformity that are widely used inside the EU). A third sectoral element of the EUSFTA looked at pharmaceuticals where the primary pledge calls for greater transparency in pricing structures. Finally, the agreement has a section on green technology: both sides pledged to allow renewable energy equipment to move between the EU and Singapore with national treatment (foreign products granted the same treatment as locally produced comparable items) and no additional conformity tests. 


\section{Trade in services}

While the agreement covers trade in goods, the primary offensive objective of the EU was to improve access to Singapore's services markets. Services could include financial services, insurance, banking, brokerage, accounting, design, architecture, legal, management, food and beverage, travel and tourism and so forth. For most developed economies, services can represent the bulk of economic activity. Even in manufactured goods, the services content of goods in cross-border supply chains can be 40-70 per cent. Hence, greater access and better protections of these key sectors were important objectives for both sides.

The EU claimed to have given Singapore levels of access comparable to the EU-Korea FTA in telecommunications, financial, computer, transport, environmental and some business services. The sections of the agreement covering postal services, the EU argued, went beyond what Korea got.

Both parties agreed that the governments may not use licensing requirements as a mechanism to obstruct entry into services markets. While licensing is not a particularly serious barrier to entry in either the EU or Singapore, this remains a favoured mechanism in many ASEAN countries to restrict foreign firm competition. Hence, the inclusion of clauses on licensing for services in the EUSFTA is primarily a marker for future ASEAN and ASEAN-wide agreements.

To ensure that both parties maintain the very best access to each other's services markets going forward and to capture whatever gains come from future negotiations with other partners, the parties agreed to include a most-favoured-nation (MFN) ratchet clause into the agreement. This means that the EU automatically receives new, matching benefits if Singapore ever negotiates an improved services agreement in any other format and vice versa for Singaporean firms entering the EU. ${ }^{5}$

5 This is, frankly, a terrible idea, but it is currently wildly popular with trade officials all over the globe who worry about losing ground to new players in future agreements. The problem with ratchet clauses is that they tie your government and markets into provisions that you had zero input in negotiating and could potentially cause harm in ways you cannot imagine. The easiest way to see the dangers is to imagine one party signing an agreement in the future with a small country in the Pacific Ocean (for example) where the economic stakes seem so modest that the agreement can afford to be incredibly ambitious. Suddenly, your own country has granted the same access through the ratchet to far more competitive firms in the partner country that could ultimately threaten domestic firms. 
The services chapter does not cover all services. Carved out of the deal are audio-visual services; national maritime cabotage; air transport; and mining, manufacturing and processing of nuclear materials. ${ }^{6}$ The Europeans were not terribly successful in getting new market access to Singapore's financial services sector. ${ }^{7}$

Services were negotiated on the basis of a 'positive list'. This is a typical negotiating style for the EU. Under a positive list approach, only the services sectors and subsectors specifically listed are opened for competition from firms in the partner country. Any new services sectors developed in the future (such as the whole industries of services generated by new technologies) are not opened unless the parties specifically negotiate such an opening in the future. ${ }^{8}$ The positive list is currently easier for the EU to use, since the individual member states can be very clear about what sorts of commitments in which subsectors they are willing to promise. Everything else not specifically noted is not opened for competition from partner firms.

In services, like in goods, an agreement includes two parts. The first is a set of rules and regulations governing the sector. The second are specific market-access promises made by each side, broken down by 12 sectors and $160+$ subsectors. In addition, in the EUSFTA, the European-side commitments are split into horizontal commitments (to apply across all subsectors in a sector), as well as establishment promises for the subsector and specific pledges on what is called mode 4 (temporary movement of personnel).

The EUSFTA opens up competition in postal services. These are services that are often considered sensitive by many governments with extensive restrictions for entry into the market.

6 As an example of the dangers of the ratchet, if not done carefully, future deals on either side could open the audio-visual sector or lead suddenly to open skies if a future agreement on either side grants such provisions (and the ratchet in the EUSFTA contains any ambiguities that would let these new rules flow through the EUSFTA). Clever lawyers can find all sorts of ways to make mischief.

7 The goal was to get comparable coverage to what the Americans received in their bilateral agreement with Singapore. But the EU was not successful in meeting this objective. See Singapore's specific commitments on financial services in Annex 8B-2 of European Commission (2015).

8 The contrasting approach is called a 'negative list'. The Trans-Pacific Partnership (TPP) and all American FTAs include a negative list. Under this style of negotiating, all services sectors except for those listed are opened to competition. This includes all future and new sectors and subsectors that are automatically opened unless the parties agree in a negotiation to close them to competition. Singapore, which has agreements with the USA and is a TPP member, negotiates services agreements using both positive and negative approaches. ASEAN, as a whole, has always used positive lists. 
Both sides agreed that telecommunications has a vital role to play in business today. They agreed to respect the confidentiality of information and to require firms to provide services on non-discriminatory terms, conditions or rates. The agreement also outlined competitive safeguards for major suppliers of telecommunications services. While the agreement does not break new ground on e-commerce, it does pledge cooperation between both sides. Both sides agreed to avoid imposing unnecessary restrictions or regulations on e-commerce activities. The agreement recognises the importance of the free flow of information and commits both sides to uphold international standards of data protection.

\section{Other new areas of coverage}

\section{Meat}

One issue of concern for Europe was Singapore's complex system of approval for meat imports. Under the EUSFTA, Singapore agreed to remove a requirement that meat products should be individually inspected and approved by the Agri-Food and Veterinary Authority (AVA) in Singapore. Going forward, Singapore agreed to set up an auditing system and allow inspections only when triggered by the auditing system.

\section{Government procurement}

Both Singapore and the EU are signatories to the Agreement on Government Procurement (GPA) at the World Trade Organization (WTO). In 2017, 19 parties are signatories. ${ }^{9}$ Under the GPA, members agree to allow certain government contracts for goods and services to be opened to firms from member states under competitive bidding.

Since both parties are included in the GPA, the EUSFTA extended the coverage areas under which tenders are to be accepted. The EU agreed to include EU central government entities, public works concessions such as railways, and some additional utilities. In addition, the EU dropped the threshold levels for bidding by Singaporean firms.

9 Counting the EU as one. www.wto.org/english/tratop_e/gproc_e/memobs_e.htm (accessed 14 May 2017). 


\section{Geographical indications}

Although the EUSFTA includes other elements in the intellectual property rights chapter, nearly all the focus was on geographical indications (GIs). This issue nearly derailed the entire negotiations and largely held up the conclusion of the agreement for nearly two years.

The basic problem is that the EU is the world's staunchest supporter of GIs, while Singapore has been generally hostile to the idea. To complicate matters further, Singapore was simultaneously negotiating an FTA with the USA and other parties in the Trans-Pacific Partnership (TPP). The TPP specifically did not include GIs, and TPP members were extremely uncomfortable with reconciling the two agreements at the end. ${ }^{10}$

A GI is a specific type of product protection. Put simply, a GI suggests that products are unique largely due to specific conditions, reputations and traditions surrounding their creation. These products cannot be recreated elsewhere and should not be allowed to bear similar names. To allow similar names is to confuse consumers who are not receiving benefits from all the specific aspects of a good.

The term originally came from wine (and subsequently spirits) production. Champagne grown in Champagne, France, is assumed to carry elements of the specific soil, weather conditions, growing traditions and bottling procedures. These elements cannot be replicated in a place like California. Whatever product gets produced in California should be called something other than champagne, such as sparkling wine, to avoid misleading consumers.

The EU has pushed for the inclusion of GIs in FTAs and has expanded the list of products beyond wines and spirits (many of which now have protections at the global level under the WTO) to items like cheeses and meats. ${ }^{11}$ Once a product receives GI protections, no other similar product

10 The resolution of this issue in the aftermath of Singapore's commitments in the EUSFTA for the TPP has been to allow GIs for 'compound names'. In general, such product designations require two names. Thus, 'feta' cheese is considered generic (and not protected). But 'Wisconsin cheddar' might qualify.

11 In the EU-Korea FTA, the GIs annex runs to 22 pages and includes a wide range of products including a host of different types of mushrooms. The EU's internal register of these products includes more than 1,000 food items and 3,000 different types of alcohol. The USA, by contrast, prefers to give products protection under trademarks, if the products meet the necessary criteria for trademark protection. 
can use the same product terms even if the label makes origin explicit. The EU tries to stop firms from producing products made 'like' or 'in the style of' or using a 'method'.

Singapore had no list of GI protections and no products that it wanted included on a list. After heated negotiations, Singapore developed a list of 196 products to be granted GI protections in the marketplace. Recognition was therefore not automatic, but subject to negotiation and approval from the regulatory authorities in Singapore. The Singapore list is particularly heavy on compound names (not just parmesan cheese, but Parmesan-Reggiano cheese or not just ham but Parma Ham) and items already protected with trademarks. In general, the stance of the Singaporean Government was to add products to the list only after determining whether such product names were viewed in Singapore as a 'generic' name. If so, products could not be granted GI protection.

Singapore added another wrinkle to the negotiations by insisting in a side letter that the entire agreement would not go into force until the GI procedures were sorted out and the list of protected GIs was confirmed by the Singapore Parliament. The bill was passed in April 2014.

\section{Competition chapter}

The agreement includes a chapter on competition policy. Both Singapore and the EU already have in place laws that are designed to prevent the growth and spread of monopolies. Hence, the chapter starts at a deeper level and commits both parties to enforcing their own respective laws on competition. The chapter also urges both sides to address the horizontal and vertical agreements between undertakings that might distort competition.

The chapter does, however, explicitly allow for public undertakings with special or exclusive rights and to maintain state monopolies. Finally, the chapter includes provisions that clarify procedures around subsidies. The agreement allows for subsidies for things such as serious disturbances to the economy; the coal industry; social character; natural disasters; economic development for abnormally low areas; certain economic activities such as research and development (R\&D), environment and supporting small and medium-sized enterprises; culture; and regional interest projects. 


\section{Trade and sustainable development}

All European agreements include a chapter on trade and sustainable development, including the EUSFTA and EU-Korea FTA. The primary purpose in these two agreements is to include binding commitments on domestic levels of environmental and labour protections consistent with core international standards and agreements.

The deal has provisions for corporate social responsibility activities, as well as conservation efforts. Fish and logging are specifically called out in the texts.

This chapter includes information about the procedures for stakeholder engagement and consultation with civil society. Finally, the chapter comes with its own dispute mechanism.

\section{Labour standards in the EUSFTA}

The agreement gives each party the right to establish their own levels of labour protection. Both sides also have the right to adopt or modify relevant laws or policies on labour. Finally, both sides committed to upholding the 1998 International Labor Organization (ILO) Declaration. Under this provision, parties agreed to the freedom of association, and effective recognition of the right to collective bargaining; elimination of all forms of forced or compulsory labour; effective abolition of child labour; and elimination of discrimination in respect of employment and occupation.

\section{Dispute settlement and management}

The agreement spells out the procedures for handling disputes. Complaints are to be handled by an arbitration panel if necessary.

The EUSFTA also sets out a strong institutional structure of committees and working groups for implementation. 


\section{Obstacles to entry into force: Who is responsible for investment now?}

Officials negotiating the agreement considered the possibility that ratification in 27 (now 28) member states might be a lengthy process. The deal allows provisional implementation to take effect during ratification by individual member states.

The effective date of the agreement, however, was thrown into turmoil by an unexpected European obstacle. The EUSFTA was the first agreement negotiated by the EU after the Lisbon Treaty took effect.

Lisbon moved competence over investment from individual member states to the European level (Meunier-Aitsahalia 2014). But it did so in a relatively unusual way. As Sophie Meunier relates, five words ('and on foreign direct investment') were added in a very late review session for the treaty that could change the way Europe deals with investment issues. Prior to this session, individual member states in Europe had their own responsibility for managing investment. Most member states had an extensive network of existing bilateral investment treaties (BITs) spanning the globe.

But once the relevant section of the Treaty on the Functioning of the European Union (TFEU or the Lisbon Treaty) came into force on 1 December 2009, the European Commission argued that responsibility for investment moved to the European level and was no longer to be handled by individual member states directly. Articles 206 and 207 of the TFEU include the phrase 'the progressive abolition of restrictions on international trade and on foreign direct investment'. Changes to the treatment of investment could be quite challenging to manage. ${ }^{12}$

After the conclusion of the treaty, some member states in the EU objected to an expansive definition of this phrase, which saw the European Commission suddenly taking over the task of handling investment negotiations as well as broader trade issues. Some members suggested that investment—at best—ought to be considered an area of 'shared

12 But a great boon to an army of consultants, lawyers and scholars to sort out in the coming years. The fate of other agreements, such as the FTA between Canada and the EU as well as ongoing early negotiations with China over a BIT, are also stuck in limbo. 
competence' with the European Commission and individual member states involved in any agreements that covered the gamut of potential investment issues like those usually handled inside an FTA or a BIT.

The EUSFTA does include broad coverage of investment. The negotiated rules cover expropriation, national treatment, fair and equitable treatment for investors from member countries, full protection and security, and free capital movements and payments. These clauses are, by now, fairly typical for recent FTA agreements between developed economies. The EUSFTA chapter will replace 12 existing BITs between Singapore and European member states.

One wrinkle in a standard investment treaty comes from Europe's status as 'not a state', which makes it ineligible for investor-state dispute settlement under the International Centre for Settlement of Investment Disputes (ICSID). Therefore, the EUSFTA provides additional venues for settling disputes over investment such as an additional facility at ICSID, the United Nations Commission on International Trade Law, and any other forum designated by the parties to a dispute. The rules allow tribunals to dispose of claims that are 'manifestly without legal merit' and 'unfounded as a matter of law'. The agreement contains three annexes that outline a mediation alternative, give a code of conduct to arbitrators, and cover procedures for transparency and access to the public of the dispute proceedings (see Shepherd 2014).

The investment chapter of the EUSFTA was handed over to the European Court of Justice to revise on 30 October 2014. The European Court of Justice delivered its ruling on 16 May 2017, and the expectation is that the agreement will now progress to ratification. ${ }^{13}$

\section{Conclusions}

The signing of the EUSFTA was a key first step on the pathway to a larger regional agreement linking Europe with ASEAN. Once the agreement clears the European Court of Justice and then the European Parliament, it will set up additional opportunities for European economic activity with Singapore and allow Singaporean companies expanded access into

13 ECJ Opinion 2/15 (Full Court), curia.europa.eu/juris/document/document.jsf;jsessionid=9ea 7d2dc30d6b9fc7709f4e94ae5a2948b05c7a3a370.e34KaxiLc3qMb40Rch0SaxyLb3r0?text=\&docid $=190727$ \&pageIndex=0\&doclang=EN\&mode=req\&dir=\&occ=first \&part $=1 \& \mathrm{cid}=470866$. 
European markets. For both sides, the agreement also includes a wide range of rules and regulations that bring greater certainty and increased transparency to business operations.

\section{References}

Delegation of the European Union to the United States (2015), 'EU and Singapore Present Text of Comprehensive Free Trade Agreement'. Available at www.euintheus.org/press-media/eu-and-singapore-presenttext-of-comprehensive-free-trade-agreement/, last accessed 15 July 2015.

European Commission (2015), 'EU-Singapore Free Trade Agreement: Authentic Text as of May 2015', 29 June. Available at trade.ec.europa. eu/doclib/press/index.cfm?id=961, last accessed 15 July 2015.

Eurostat (2013), Eurostat online database. Available at ec.europa.eu/ eurostat/data/database.

Herbert Smith Freehills (2014), 'European Commission requests European Court of Justice Opinion on competence to enter into EUSingapore FTA', 6 November. Available at hsfnotes.com/publicinter nationallaw/2014/11/06/european-commission-requests-europeancourt-of-justice-opinion-on-competence-to-enter-into-eu-singapore$\mathrm{fta} /$, last accessed 15 July 2015.

Meunier, Sophie (2017), 'Integration by Stealth: How the European Union Gained Competence over Foreign Direct Investment Policy'. Journal of Common Market Studies 55(3): 593-610. doi.org/10.1111/ jcms.12528.

Ministry of Trade and Industry, Singapore (2015), 'Singapore and the European Union Initial the Investment Protection Chapter', Press release, 22 May. Available at www.mti.gov.sg/NewsRoom/SiteAssets/ Pages/Singapore-and-the-European-Union-Initial-the-InvestmentProtection-Chapter-/Press \%20release \%20on \%20EUSFTA\%20 IPC\%20Initialling.pdf, last accessed 15 July 2015.

Shepherd, Jordan (2014), 'EU-Singapore FTA Concluded, but EU Ratification May Be Delayed', Lexology, 19 December. Available at www.lexology.com/library/detail.aspx?g=4e 5 fc749-bbb0-4bb1-9ee2473a302877e1, last accessed 15 July 2015. 
This text is taken from Australia, the European Union and the New Trade Agenda, edited by Annmarie Elijah, Don Kenyon, Karen Hussey and Pierre van der Eng, published 2017 by ANU Press, The Australian National University, Canberra, Australia. 